\title{
Knowledge and Perception of Asthmatic Patients and their Family towards Asthma Disease and Management in King Saud Medical City, Riyadh, KSA
}

Donques AA*, Alaki E, Almazyad W and Almutairi A

King Saud Medical City, Riyadh, Saudi Arabia

*Corresponding author: Donques AA, King Saud Medical City, Riyadh, Saudi Arabia, Tel: +966567669989; E-mail: dr.aziza-alali@hotmail.com

Received date: April 20, 2017; Accepted date: June 6, 2017; Published date: June 19, 2017

Copyright: (c) 2017 Donques AA. This is an open-access article distributed under the terms of the Creative Commons Attribution License, which permits unrestricted use, distribution, and reproduction in any medium, provided the original author and source are credited.

Abstract
Background: Despite of the major effort to improve asthma management, there are still poor public knowledge
and perception among patients with asthma and their family in the Kingdom of Saudi Arabia.
Methods: Across sectional descriptive study was conducted last May 20, 2015 during World Asthma Day at
Medical Tower ground floor in King Saud Medical City in Riyadh, Kingdom Saudi Arabia with more than 100
participants in the said activity from different area of Riyadh. Questionnaires were distributed to the participants after
given asthma awareness by healthcare providers.
Results: A total of 55 participants during Asthma day responded to the questionnaire, Majority are male (50.94\%)
and Saudi nationality ( $67.92 \%)$. After intervention and awareness given to the participants, most of them are aware
that asthma is shortness of breath and coughing ( $87 \%)$ which considered being the major signs and symptoms of
asthma. Furthermore they don't believe that abdominal pain causes asthma (25\%). Participants are aware that most
of the common risk factors of asthma is exposure to smoke (94\%) followed by exposure to polluted air (91\%). The
knowledge and perception of the participants towards the medication needs to be used for asthma, most of them
answered ventolin spray ( $77 \%$ ) and followed by oxygen (72\%).
Conclusions: Different model of educational activity for bronchial asthma helps in improving the knowledge and
awareness of patients and family about asthma disease.

Keywords: Asthma awareness; Knowledge; Perception; Pediatrics; Healthcare

\section{Introduction}

Bronchial Asthma is well known disease all over the world and it is one of the most common chronic illnesses in Kingdom of Saudi Arabia (KSA). Local reports suggest that the prevalence of asthma is increasing [1]. Poor knowledge, fear use of new drugs and lack of awareness about the importance to control the disease are common among primary care physicians caring for asthma patients in the KSA [2].

Education awareness is considered to be effective problem-solving approach to the delivery of health care that standardized the management of patient's preferences and values in making the best clinical decisions about asthma [3]. Several asthma patients continue to be under diagnosed, under treated and at risk of acute exacerbations resulting in absent from work or school, increased use of expensive acute healthcare services and reduced quality of life [3].

Lack of awareness, poor compliance in attending educational session and not participating in asthma day activity are the most common factors that lead to increased uncontrolled asthma patients. A recent asthma control survey showed that only $5 \%$ were controlled, $31 \%$ were partially controlled and $64 \%$ were uncontrolled [4].

One study conducted last September 26, 2013 which is to know the knowledge, attitude and practices of patients of bronchial asthma which has a total of 140 patients with confirmed diagnosis of asthma [5].

Both of the study concluded that patient education program should augment awareness, eliminate social stigma and misconcepts in the community regarding asthma. Knowledge about the prevailing perception in the community would be the first step in achieving this. Another descriptive cross-sectional study was conducted and 100 diagnosed asthmatic children and their caregivers were enrolled.

This study concluded that asthma awareness is inadequate, and asthmatic children are deprived of nutritious food considering them as triggering factors. Awareness raising strategies are needed in community [6]. A wide gap exists between recommended and actual practice, owing to educational barriers and a lack of adequate asthmarelated knowledge [7].

World Asthma Day is one of the best methods in giving awareness to the public as in like May 5, 2015 with the theme "You Can Control Your Asthma" [8]. In KSA, this activity was celebrated in most of the healthcare organizations following the same theme; King Saud Medical City (KSMC) was among them. Activity was conducted on May 20, 2015 at Medical Tower of KSMC, Riyadh.

In line to this activity, the researchers took the opportunity to evaluate the knowledge and perception of the participants towards asthma disease and its management through questionnaires distributed to them right before they will leave the activity area. 
Citation: Donques AA, Alaki E, Almazyad W, Almutairi A (2017) Knowledge and Perception of Asthmatic Patients and their Family towards Asthma Disease and Management in King Saud Medical City, Riyadh, KSA. J Clin Respir Dis Care 3: 128. doi: $10.4172 / 2472-1247.1000128$

Page 2 of 5

\section{Objectives}

- To assess the knowledge of parents caring for asthmatic children about Asthma; its risk factors, treatment, and prevention.

- To identify the perception of parents caring for asthmatic children about Asthma disease in general.

\section{Materials and Methods}

A cross sectional descriptive study was conducted on May 20,2015 whole day activity was carried out from 7:30 AM up to 6:00 PM entitled "World Asthma Day".

The activity was held in Medical Tower ground floor of KSMC in Riyadh, KSA organized by allergy and immunology physicians, epidemiologists, health educators, nurses and respiratory therapists and other allied healthcare providers.

Study population: All participants who have children or relative ages between 0-12 years old diagnosed with asthma or any history of asthma regardless of gender and nationality.

Sample size: 100 questionnaires were prepared, 80 were distributed to the attendees, 55 were received, 11 were not filled up completely and 14 were not given back.

Study materials: There were different activities during this event like putting stations along with stands (example: triggering factors, asthma medications, risk factors etc.), distribution of brochures, play area for the kids, showing educational movies and distribution of gifts.

Questionnaires were developed and prepared in bi-language (English and Arabic) reviewed by Epidemiologist and finalized by the Allergist and Immunologist consultants covering all the requirements in the questionnaire. Each questionnaire has four parts as follows:

Part 1: Demographic data (Age of the asthmatic child, gender, nationality, number of family members who have asthma, number of children with asthma).

Part 2: General questions (ideas about the information towards asthma and clinical symptoms).
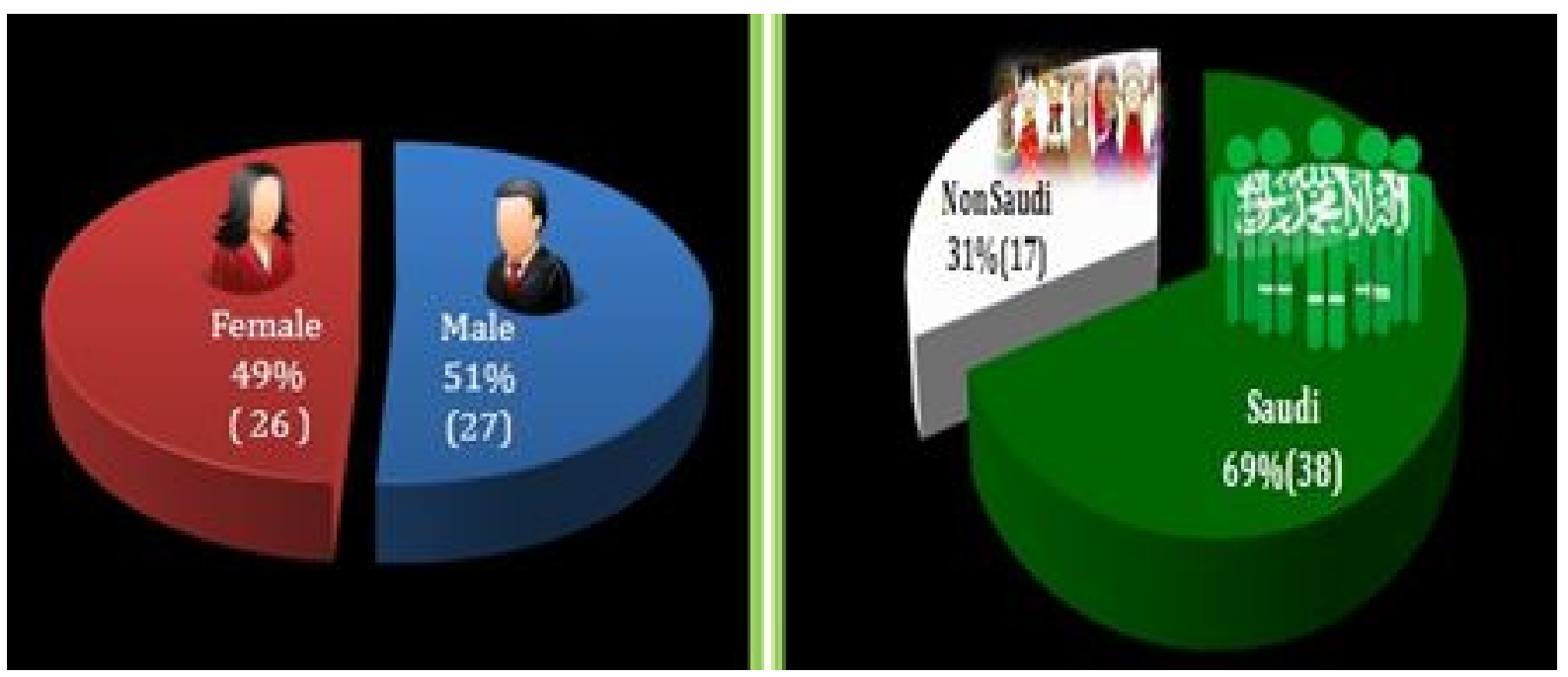

Figure 1: Gender of participants and nationality.
Part 3: Risk factors and education (ideas of possible irritant factors such as cold weather, dust, pets; medication use, asthma management, protective steps \& procedures to perform in case of asthma attack).

Part 4: Health education received by the participants (type of health education, information received and who provided the health education).

Ethical considerations: The study objectives were explained clearly to the participants and verbal consent were obtained from all of them. Their rights to refuse in participation and the confidentiality were stated. Ethical approval was obtained from IRB committee in KSMC.

Data collection and analysis: Data was collected through questionnaires and analyzed through SPSS windows software, Version 20.0. The level of significance tested by chi square and $P$ value $<0.05$.

\section{Results}

A total of 55 participants during Asthma day responded to the questionnaire with mean age of their children with bronchial asthma represented 4.65; maximum age is 12 and minimum is 1 year old (Table 1).

\begin{tabular}{|l|l|}
\hline Sample Size & $\mathbf{N}=\mathbf{5 5}$ \\
\hline Age & $4.65(3.34)$ \\
\hline Mean (SD) & 4 \\
\hline Median & 1 \\
\hline Minimum & 12 \\
\hline Maximum & \\
\hline
\end{tabular}

Table 1: Mean, median, minimum and maximum of age of asthmatic children.

About $69 \%$ of the participants were of Saudi nationality; $49 \%$ were females and $51 \%$ males (Figure 1). 
Citation: Donques AA, Alaki E, Almazyad W, Almutairi A (2017) Knowledge and Perception of Asthmatic Patients and their Family towards Asthma Disease and Management in King Saud Medical City, Riyadh, KSA. J Clin Respir Dis Care 3: 128. doi: $10.4172 / 2472-1247.1000128$

Page 3 of 5

After intervention and awareness given to the participant most of them were aware that asthma is shortness of breath and coughing (87\%) which considered being the major signs and symptoms of asthma. Furthermore they didn't believe that abdominal pain causes asthma (25\%) (Figure 2).

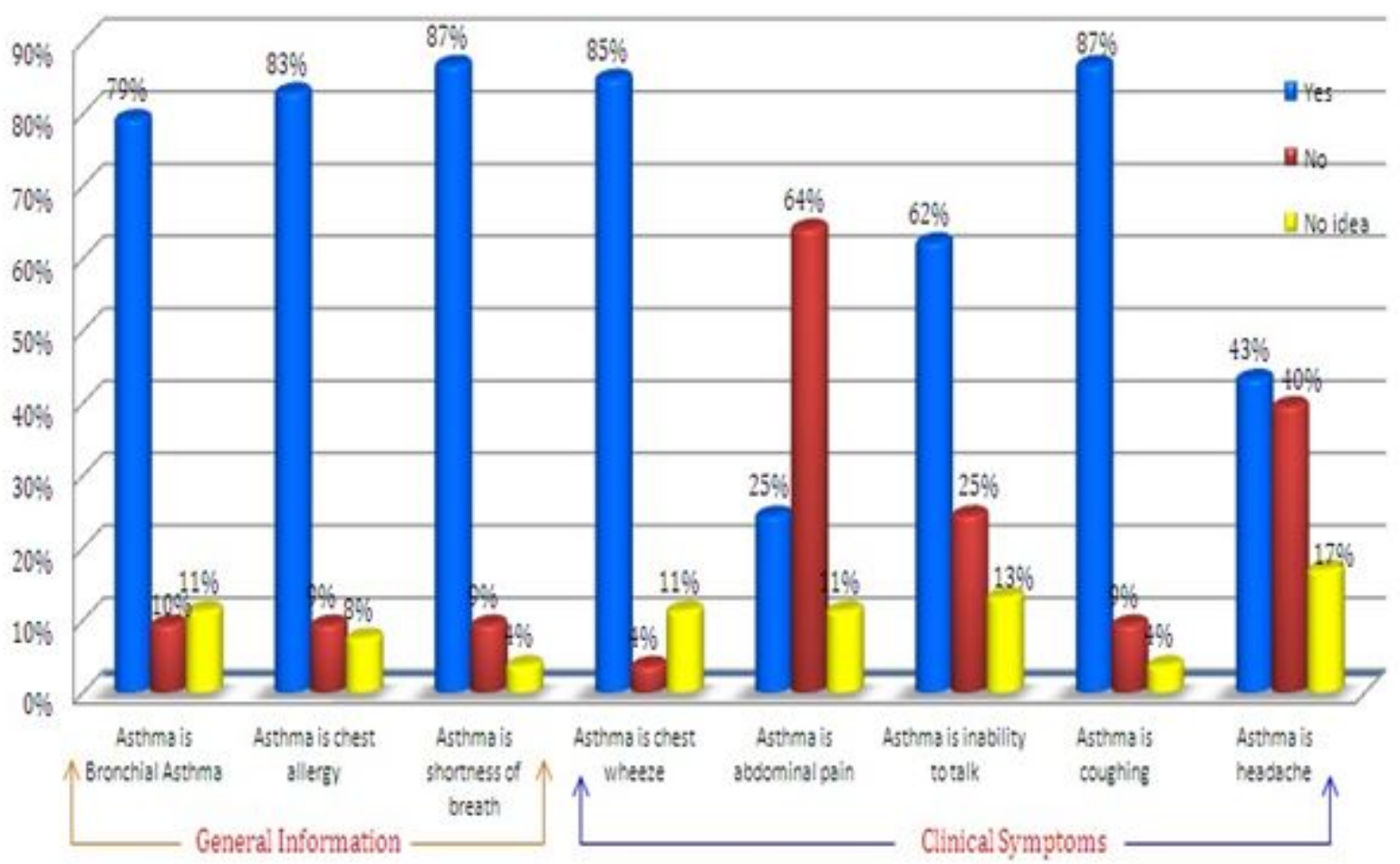

Figure 2: Knowledge and perception about asthma.

Participants were aware that most of the common risk factors of asthma is exposure to smoke (94\%) followed by exposure to polluted air (91\%) (Figure 3).

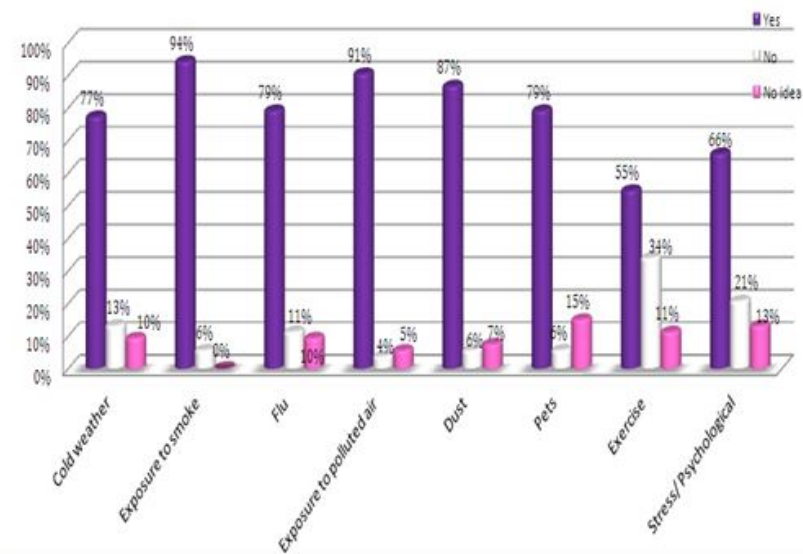

Figure 3: Knowledge and perception about asthma risk factors.
The knowledge and perception of the participants towards the medication needs to be used for asthma, most of them answered ventolin spray (77\%) and followed by oxygen (72\%) (Figure 4).

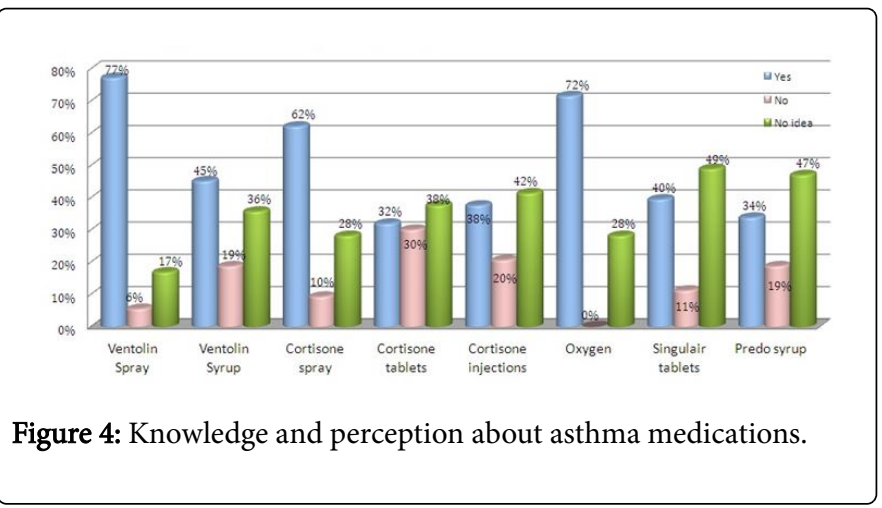

There were $80 \%$ of participants who said YES; they received health education and $20 \%$ of them didn't (Figure 5). 
Citation: Donques AA, Alaki E, Almazyad W, Almutairi A (2017) Knowledge and Perception of Asthmatic Patients and their Family towards Asthma Disease and Management in King Saud Medical City, Riyadh, KSA. J Clin Respir Dis Care 3: 128. doi: $10.4172 / 2472-1247.1000128$

Page 4 of 5

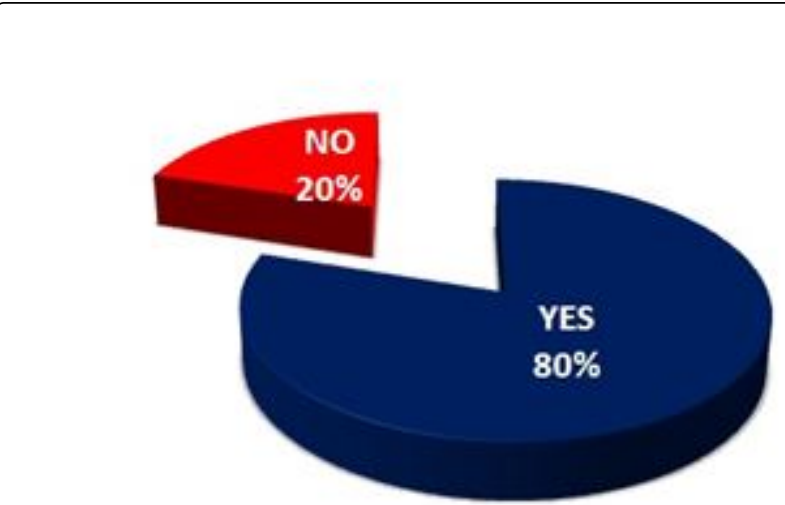

Figure 5: Received health education about asthma.
The Statistical Relationship between Parents Ideas and Beliefs towards Asthma and Received Health Education about Asthma showed that there is statistically significance relationship $(\mathrm{P}=0.009$, chi-square $=9.35$ ) between the parents Received health education about asthma and their beliefs and ideas about "Asthma can be recovered under good control" (Table 2).

Furthermore, there is no relationship between the parent's ideas and beliefs about asthma with the content of health education received such as improving and increasing the information about asthma changing some behaviors and beliefs about asthma and developing the skills of curing with $P$ value $>0.05$ and $d f=8$. The study showed that there is statistically significance relationship between the parent's beliefs and ideas about asthma can be cured ( $\mathrm{P}$ value $=0.02)$; asthma is a genetic disease $(\mathrm{P}$ value $=0.04)$; asthma is psychological disease $(\mathrm{P}$ value $=0.01)$ and using ventolin leads to addiction $(\mathrm{P}$ value $=0.05)$ with the Kind of health education provided (Table 3 ).

\begin{tabular}{|c|c|c|c|c|c|c|}
\hline Parents ideas and beliefs & \multirow{2}{*}{$\mathbf{N}$} & \multicolumn{2}{|c|}{ Received health education about asthma } & df & \multirow{2}{*}{ Chi-square } & \multirow{2}{*}{ P-Value } \\
\hline Asthma can be recovered under good control & & Yes & No & & & \\
\hline YES $=58.2 \%(32)$ & \multirow{3}{*}{55} & \multirow{3}{*}{$80 \%(44)$} & \multirow{3}{*}{$20 \%(11)$} & \multirow{3}{*}{2} & \multirow{3}{*}{9.35} & \multirow{3}{*}{0.009} \\
\hline $\mathrm{NO}=10.9 \%(6)$ & & & & & & \\
\hline NO IDEA=30.9\% (17) & & & & & & \\
\hline
\end{tabular}

Table 2: Relationship between parent's ideas and beliefs towards asthma with received health education about asthma.

\begin{tabular}{|c|c|c|c|c|c|c|c|c|}
\hline Parents ideas and beliefs & \multicolumn{5}{|c|}{ Kind of health education provided } & df & Chi-square & P-value \\
\hline $\begin{array}{l}\text { Asthma can be cured } \\
\text { YES }=40 \% \text { (22) }\end{array}$ & Lectures & $\begin{array}{l}\text { Booklets/ } \\
\text { brochures }\end{array}$ & $\begin{array}{l}\text { Personal } \\
\text { advice }\end{array}$ & $\begin{array}{l}\text { Attending } \\
\text { previous } \\
\text { asthma day }\end{array}$ & Others & \multirow[t]{2}{*}{10} & \multirow[t]{2}{*}{17.93} & \multirow[t]{2}{*}{0.02} \\
\hline NO IDEA=38.2\% (21) & \multirow{4}{*}{$\begin{array}{l}25.5 \% \\
(14)\end{array}$} & \multirow{4}{*}{$\begin{array}{l}18.2 \% \\
(10)\end{array}$} & \multirow{4}{*}{$\begin{array}{l}5.5 \% \\
(3)\end{array}$} & \multirow{4}{*}{$\begin{array}{l}10.9 \% \\
(6)\end{array}$} & \multirow{4}{*}{$\begin{array}{l}40 \% \\
(22)\end{array}$} & & & \\
\hline $\begin{array}{l}\text { Asthma is a genetic disease } \\
Y E S=32.7 \%(18) \\
N O=27.3 \%(15) \\
N O \text { IDEA }=40 \%(22)\end{array}$ & & & & & & 10 & 15.03 & 0.04 \\
\hline $\begin{array}{l}\text { Asthma is a psychological disease } \\
\text { YES }=32.7 \%(18) \\
N O=32.7 \%(18) \\
\text { NO IDEA }=34.5 \%(19)\end{array}$ & & & & & & 10 & 16.85 & 0.01 \\
\hline $\begin{array}{l}\text { Using Ventolin } \\
\text { leads to addiction } \\
\text { YES }=34.5 \%(19) \\
\text { NO=27.3\% (15) } \\
\text { NO IDEA }=38.2 \%(21)\end{array}$ & & & & & & 10 & 14.53 & 0.05 \\
\hline
\end{tabular}

Table 3: Parents ideas and beliefs towards asthma with the kind of Health Education Provided $(\mathrm{N}=55)$.

The statistical significance relationship between parent's ideas and beliefs towards asthma with the attendance of previous asthma day showed that there is statistically significance relationship between the parents beliefs and ideas about asthma and can be recovered under good control $(\mathrm{P}=0.01)$; asthma is genetic disease $(\mathrm{P}=0.04)$ and ventolin increase heartbeats $(\mathrm{P}=0.03)$ with the attendance of previous asthma day (Table 4). 
Citation: Donques AA, Alaki E, Almazyad W, Almutairi A (2017) Knowledge and Perception of Asthmatic Patients and their Family towards Asthma Disease and Management in King Saud Medical City, Riyadh, KSA. J Clin Respir Dis Care 3: 128. doi: $10.4172 / 2472-1247.1000128$

Page 5 of 5

\begin{tabular}{|c|c|c|c|c|c|}
\hline Parents ideas and beliefs & $\begin{array}{l}\text { Attendar } \\
\text { activity }\end{array}$ & of previous asthma day & df & Chi square & P-value \\
\hline Asthma can be recovered under good control & YES & NO & & & \\
\hline NO $\mathrm{NDEA}=10.9 \%(6)$ & \multirow{3}{*}{$\begin{array}{l}30.90 \% \\
(44)\end{array}$} & \multirow{3}{*}{$\begin{array}{l}69.1 \% \\
(38)\end{array}$} & 4 & 9.43 & 0.01 \\
\hline $\begin{array}{l}\text { Asthma is a genetic disease } \\
\text { YES }=32.7 \%(18) \\
\text { NO }=27.3 \%(15) \\
\text { NO IDEA }=40 \%(22)\end{array}$ & & & 4 & 8.49 & 0.04 \\
\hline $\begin{array}{l}\text { Ventolin increase heartbeat } \\
\text { YES }=43.6 \%(24) \\
\text { NO }=10.9 \%(6) \\
\text { NO IDEA }=45.5 \%(25)\end{array}$ & & & 4 & 7.28 & 0.03 \\
\hline
\end{tabular}

Table 4: Parents ideas and beliefs towards asthma with the attendance of previous Asthma Day ( $\mathrm{N}=55)$.

\section{Discussion}

Optimal asthma education is an integral part of asthma management which decreases asthma related morbidity improves inhalation technique and asthma knowledge [9]. The study showed that there was statistically significant between parent's belied and ideas towards asthma with the attendance of asthma activity. Health education and awareness activity showed great impact on parent's knowledge and perception because some of the parents have accurate beliefs and other inaccurate based on clinical perception.

Aiming for the public in giving awareness session about asthma and involving children in this research brought multipart challenges to the study. The researchers mentioned some of the limitations during the collection of data which include space during the activity it was conducted in the hospital and it's hard to catch most of the public not like in malls or park $[1,2]$.

Less number of health educators during the activity; it takes time to educate and cover all the participants. Considering a participatory approach and following interactive learning methods were very resource intensive both financially but also in terms of staff time and staff engagement.

\section{Acknowledgement}

The authors wish to acknowledge the support of the team from different departments leaded by Dr. Emadia Alaki of King Saud Medical City, Riyadh for participation in the asthma day activity and sponsors from different companies to have a successful asthma day activity. We would like to extend special appreciation to all the study participants who willingly participated and by responding to the questionnaires distributed. Thanks are also extended to IRB committee of KSMC which provided grants to assist in this study and its report. This report is dedicated to those children with asthma and their parents who continue in hope for a better quality of life.

\section{References}

1. Al-Moamary MS, Al-Hajjaj MS, Idrees MM, Zeitouni MO, Alanezi MO, et al. (2009) The saudi initiative for asthma. 4:216-232.

2. Abudahish A, Bella H (2006) Primary care physicians perceptions and practices on asthma care in Aseer region, Saudi Arabia. Saudi Med J 27: 333-337.

3. Melnyk BM (2015) Important information about clinical practice guidelines: Key tools for improving quality of care and patient outcomes. Worldviews Evid Based Nurs 12: 1-2.

4. GINA (2017) World Asthma Day.

5. Sodhi R, Prasad R, Kushwaha RAS, Kant S, Verma SK, et al. (2013) A study to know the knowledge, attitude and practices of patients of bronchial asthma. Int J Med Public Health 3: 159-162.

6. Awan AS, Munir SS (2015) Asthmatic children; Knowledge, attitude and practices among caregivers. Professional Med J 22: 130-136.

7. Clatworthy J, Price D, Ryan D, Haughney J, Horne R (2009) The value of self-report assessment of adherence, rhinitis and smoking in relation to asthma control. Prim Care Respir J 18: 300-305.

8. GINA (2017) World Asthma Day: Physician \& pharmacist were trained on technique of asthma diagnostic kits.

9. Barthwal MS, Katoch CDS, Marwah V (2009) Impact of optimal asthma education programme on asthma morbidity, inhalation technique and asthma knowledge. J Assoc Physicians India 57: 574-579. 